\title{
Yabani-Ekşi Elmanın (Malus sylvestris Miller) Antioksidan Aktivite ve Fenolik Madde İçeriği Üzerine Farklı Kurutma Yöntemlerinin Etkisi
}

\author{
Kübra GÜLDEMIIR ${ }^{1 *}$, Özlem ÇAKIR ${ }^{2 *}$, Kübra ÇAKIROĞLU $^{3}$ \\ ${ }^{1}$ G1da Mühendisliği, Mühendislik Fakültesi, İnönü Üniversitesi, Malatya, Türkiye \\ $2^{2 *}$ Gıda Mühendisliği, Mühendislik Fakültesi, Bayburt Üniversitesi, Bayburt, Türkiye \\ ${ }^{3}$ Trabzon İl Gida Kontrol Laboratuvarı, Tarım ve Orman Bakanlığı, Trabzon, Türkiye \\ ${ }^{1}$ kguldemir@gmail.com, ${ }^{2 *}$ ocakir@ bayburt.edu.tr, ${ }^{3}$ kubraaksehir@ $@$ hotmail.com
}

Öz: Bu çalışma kapsamında, Bayburt çevresinde yetişen yabani ekşi elma (Malus sylvestris Miller) örneği dört farklı kurutma yöntemi (infrared kurutma, sıcak havada kurutma, oda sıcaklığında kurutma ve dondurarak kurutma) ile kurutulmuş ve kurutulan ürünlerin fenolik madde içeriği ve antioksidan aktiviteleri belirlenmiştir. Kurutma yöntemlerine göre toplam fenolik madde içerikleri açısından en düşük değer oda şartlarında kurutulmuş elma örneğinde (34.92 mg GAE/g KM), en yüksek değer ise sicak havada kurutulmuş örnekte (41.18 mg GAE/g KM) tespit edilmiştir. Yabani ekşi elma örneklerinin antioksidan aktivite seviyeleri; FRAP yöntemine göre "dondurarak kurutma $>$ sıcak havada kurutma $>$ infrared kurutma $>$ oda sıcaklığında kurutma" şeklinde, CUPRAC yöntemine göre "sıcak havada kurutma $>$ dondurarak kurutma $>$ infrared kurutma $>$ oda sıcaklığında kurutma" şeklinde, $\beta$-karoten yöntemine göre ise dondurarak kurutma $>$ sıcak havada kurutma $>$ oda sıcaklığında kurutma>infrared kurutma şeklinde değiştiği belirlenmiştir. CUPRAC metodu ile FRAP metodu arasında yüksek bir korelasyon olduğu saptanmıştır $\left(\mathrm{r}=0.939, \mathrm{R}^{2}=\% 88\right)$. Elde edilen deneysel verilere göre, antioksidan ve fenolik madde içeriği açısından yabani ekşi elma (Malus sylvestris Miller) için en iyi kurutma yönteminin sıcak havada kurutma olduğu tespit edilmiştir. Renk değerleri açısından en iyi yöntemin dondurarak kurutma olduğu belirlenmiştir.

Anahtar Kelimeler: Kurutma, antioksidan, fenolik madde, yabani elma, Bayburt.

\section{Effect of Different Drying Methods on The Antioxidant and Phenolic Compounds of Malus sylvestris Miller}

Abstract: Wild sour apples (Malus sylvestris Miller) in Bayburt province were dried by four different drying methods. The phenolic content and antioxidant activities of the dried products were determined. The effect of drying methods on the biochemical properties of the product was investigated. Four different drying methods (infrared, hot air, room conditions, freezing) were discussed. The lowest phenolic content is determined as $34.92 \mathrm{mg} \mathrm{GAE} / \mathrm{gKM}$ in room drying and the highest is $41.18 \mathrm{mg} \mathrm{GAE} / \mathrm{gKM}$ in hot air drying. Most suitable drying method changes according to antioxidant activity determining methods. According to DPPH, the most suitable drying technique is hot air drying. According to the FRAP method sort from good to bad like this: "freezing drying $>$ hot air $>$ infrared $>$ room temperature", according to the CUPRAC; hot air $>$ freezing $>$ infrared > room temperature, while in Beta carotene method the sequence was found as freezing > hot air > room temperature> infrared. There is a high correlation between CUPRAC and FRAP $\left(\mathrm{r}=0.939, \mathrm{R}^{2}=88 \%\right)$. In terms of antioxidant and phenolic content, the best drying method is determined as hot air drying method. In terms of color values and browning, the best method was found to be freeze drying.

Key words: Drying, antioxidant, phenolic content, wild sour apple, Bayburt.

\section{Giriş}

Elmanın dünyada oldukça geniş bir yetişme alanı olup 7400 çeşidi bulunmaktadır. Bu meyvenin en çok yetiştiği ülkelerden biri de Türkiye olup Anadolu toprakları farklı elma çeşitleri konusunda oldukça zengindir. Anadolu'nun farklı bölgelerinde kültüre alınmış ya da alınmamış birçok elma çeşidi yetişmektedir. Kuzey Anadolu elma yetişen yerler arasında başı çekmekte olup Karadeniz kıyı bölgesi ile İç Anadolu ve Doğu Anadolu yaylaları da elmanın yetişmesi için oldukça uygun bölgelerdir [1].

Elma meyvesinin dünyanın neredeyse her yerinde ve değişik şartlarda yetişebilmesi, birçok farklı çeşidinin var olması ve buna bağlı olarak farklı lezzetler sunması, kolay depolama imkânının bulunması gibi özelliklerinden dolayı yaygınlığı oldukça fazladır. Bunların yanı sıra ihtiva ettiği besin içeriği ve değerli fitokimyasallar da bu meyveyi en çok tercih edilen besin kaynaklarından biri haline getirmektedir. Diğer meyvelerle karşılaştırıldığında en önemli flavanoid kaynaklarından biri elmadır. Bununla birlikte oldukça güçlü

\footnotetext{
* Sorumlu yazar: kguldemir@gmail.com. Yazarların ORCID Numaras:: ${ }^{1}$ 0000-0002-7397-3335, ${ }^{2}$ 0000-0002-5080-7721, ${ }^{3}$ 0000-00034616-9103
} 
antioksidan aktiviteye sahip olan fitokimyasallar içermektedir [2, 3]. Bu fitokimyasalların büyük bir kısmı fenolik bileşiklerden oluşmaktadır [3,4]. Elmanın en belirgin fenolik bileşikleri flavonoidler; flavonoller ve flavanoller olup bunlar sadece elmalara özgü olan dihidrokalkonlardan oluşmaktadır. Elmada diğer fenolik bileşenlerden en çok klorojenik asit bulunmaktadır [2, 3, 5]. Burada bahsi geçen polifenollerin antioksidan özelliklerinden dolayı kardiyovasküler rahatsızlıklar, obezite, kanser veya diyabet gibi bazı hastalıkların riskini azalttığı bilinmektedir [6, 7,8].

Kültüre alınmış ya da yabani birçok türü bulunan elmanın önemli çeşitlerinden biri de ekşi elma olarak bilinen Malus sylvestris Miller'dir. Ekşi elma genellikle dağ yamaçlarında ve kırsal arazilerde doğal olarak yetişen bir meyvedir. Bu elma türü ekonomik bir ürün olmamakla birlikte yetiştiği yörelerde farklı şekillerde ve değişik amaçlarla tüketilmektedir. Ekşi elmanın en yoğun olduğu yerlerden biri Bayburt olup bu yörede çay ile birlikte yoğun olarak tüketilmektedir. Çaya limon yerine ekşi elma ilave edilerek hem çok güçlü olan aromasından faydalanılmakta hem de hastalıkları önleyici olarak değerlendirilmektedir. Buna ilaveten marul ve çoban salatalarının içinde de kullanılabilmektedir [9]. Ayrıca elma suyu, elma çayı, elma sirkesi, elma şarabı, elma pekmezi, elma hoşafi gibi ürünlere de işlenebilmektedir. Ekşi elma sadece mevsiminde değil diğer mevsimlerde de çok yoğun bir şekilde kullanılmaktadır. Yöre insanları ekşi elmayı salamura veya turşu yaparak, dondurarak ya da kurutarak muhafaza etmektedir.

Meyvelerin kurutulması en eski muhafaza yöntemlerinden biri olup, günümüzde de en çok başvurulan metotların başında gelmektedir. Bu yöntem ekşi elmanın muhafaza edilmesi amacıyla da oldukça sık kullanılmaktadır. Ancak kurutmanın elmaya uygulanması durumunda rastlanabilecek problemler ve çözümler konusunda henüz tam bir ittifak sağlanamamış olup yeni ve farklı kurutma yöntemlerinin meyvelerin besinsel ve fizikokimyasal özelliklerine etkisi üzerine yapılan çalışmalar halen devam etmektedir. Meyvelerde eksik ya da fazla kurutma yapılması, meyvelerin raf ömrü, besinsel içeriği ve fizikokimyasal yapısı üzerinde olumsuz etkilere neden olabilmektedir [10].

$\mathrm{Bu}$ çalışmada, Bayburt ilinde doğal olarak bulunan yabani ekşi elma meyvesi pomolojik olarak incelenmiştir Sonrasında ise farklı kurutma işlemlerinin, meyvenin antioksidan ve fenolik madde içeriği üzerindeki etkileri araştırılmıştır. Bu kapsamda doğal ortamından en uygun mevsim ve zamanda toplanan ekşi elma meyveleri farklı kurutma yöntemleri (infrared, sıcak hava, oda koşulları, dondurarak) ile kurutulmuştur. Daha sonra yapılan çeşitli analizlerle kurutulmuş ürünlerin antioksidan aktivite ve fenolik madde içeriklerindeki değişim irdelenmiş ve farklı kurutma yöntemleri karşılaştırılıp en uygun kurutma yöntemi tespit edilmiştir.

\section{Materyal ve Yöntem}

Bu çalışma yabani elmanın yoğun olarak bulunduğu Bayburt ilinde yürütülmüştür. İlin farklı yerlerinde bulunan dağlık arazilerden toplanan yabani ekşi elmalar (Şekil 1) ivedilikle çalışmanın yapıldığı laboratuvarlara getirilerek yapılması gereken ilk işlemler gerçekleştirilmiştir. Sonrasında numuneler buzdolabına $\left(+4^{\circ} \mathrm{C}\right)$ konulmuş ve vakit kaybetmeden ölçüm ve analizlere başlanmıştır. Dondurarak kurutulacak meyveler işlemlerin yapılacağı zamana kadar $-80^{\circ} \mathrm{C}$ 'de muhafaza edilmiştir.

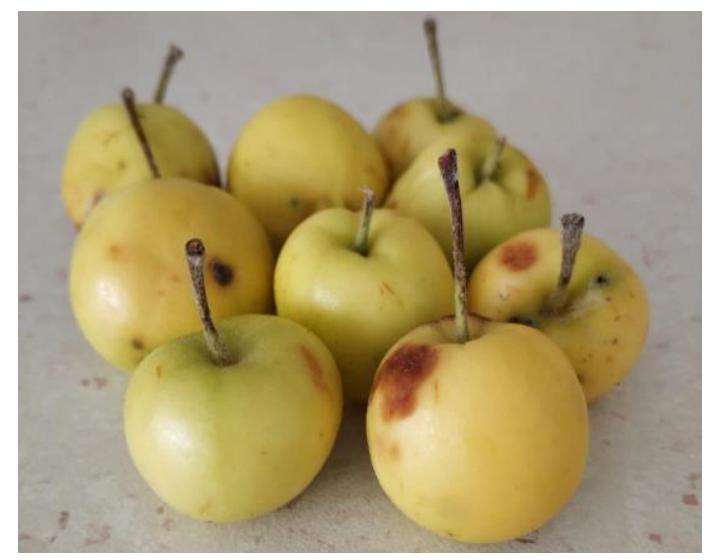

Şekil 1. Yabani ekşi elma. 


\subsection{Yöntem}

Pomolojik analizler, elma ağaçlarının çeşitli yönlerinden alınan 30 adet meyve üzerinde yapılmıştır. Meyve boyu ve eni 30 adet meyvede, 0.01 mm'ye duyarlı dijital kumpas ile ölçülmüştür. Meyve ağırllğ 1 ise 30 adet meyve üzerinde 0.05 g'a duyarlı dijital teraziyle belirlenmiştir. Meyve hacmi ölçülü silindirde taşırdıkları su miktarına göre belirlenmiştir. Meyvelerin çekirdekleri 0.05 g'a duyarlı dijital teraziyle tartılarak 30 adet meyve çekirdeği kullanılarak belirlenmiştir.

Meyvelerin suda çözünen kuru madde miktarı (SÇKM) dijital refraktometre (Model Ra 250HE, Kyoto Electronics Manufacturing Co. Ltd. Japon) kullanılarak ölçülmüştür. Meyvelerden elde edilen meyve suları kullanılarak elektronik $\mathrm{pH}$ metre yardımıyla elmaların $\mathrm{pH}$ ölçümü gerçekleştirilmiştir. Ölçüm esnasında elektrotlar $\mathrm{pH}$ değeri sabitleninceye kadar örnek içerisinde yaklaşık 1-2 dakika tutularak sonuçlar belirlenmiştir. Renk tayin işlemi için ise Minolta CR-300 renk tayin cihazı kullanılmıştır. Buradaki ölçüm işlemi L (100: beyaz, 0: siyah), a (+: kırmızı, -: yeșil), b (+: sarı, -: mavi) parametrelerine göre yapılmıștır. Renk tayini için rastgele seçilen 30 adet meyve kullanılmıştır. Meyvelerin askorbik asit, toplam asitlik, malik asit ve glikoz içeriği 'RQflex plus 10' (MERCK, Germany) cihazı ile tespit edilmiştir.

\subsection{Kurutma yöntemleri}

Elmalar yıkanıp çekirdekleri çıkarıldıktan sonra dilim şeklinde doğranıp oda sıcaklığı, sıcak hava, infrared ve dondurarak (liyofilize) olmak üzere 4 farklı yöntemle kurutulmuştur. Dondurarak kurutma işlemi için Heto CD4 marka liyofilizatör kullanılmıştır. Dondurucudan çıkan dilimlenmiş elmalar tepsilere konularak liyofilizatöre yerleştirilmiş ve işlem $-55^{\circ} \mathrm{C}$ ve $>0.5$ mbar altında gerçekleşmiş ve nem içeriği $\% 9$ oluncaya kadar kurutulmuştur. Oda sıcaklığında kurutma işlemi laboratuvar ortamında gerçekleştirilmiştir. Elmalar dilimlenip birbirine karışmayacak şekilde dizilerek oda sıcaklığında kurumaya bırakılmıştır. Etüvde kurutma işleminde elma dilimleri $65^{\circ} \mathrm{C}$ de sabit tartıma gelinceye kadar kurutulmuştur. İnfrared kurutma işleminde elma dilimleri yaklaşık $50 \mathrm{~cm}$ mesafede yerleştirilen $2500 \mathrm{kw}$ gücündeki infrared isıtıcının karşısına yerleştirilmiştir. Bahsi geçen her dört yöntem de ürünlerin nem oranı \%8-10 aralığına gelinceye kadar uygulanmıştır.

\subsection{Antioksidan aktivite}

Bu çalışma kapsamında dört farklı antioksidan aktivite belirleme metodundan yararlanılmıştır. Uygulanan ekstraksiyon ile antioksidan metotları aşağıda açıklanmıştır.

Meyveleri temsil edecek şekilde alınan $100 \mathrm{~g}$ kurutulmuş meyve örneği karıştırıcı kullanılarak homojen bir hale getirilmiştir. Buradan alınan örneğin çözeltisi hazırlanarak bir saat boyunca tüpler içerisinde ekstraksiyonu sağlanmıştır [11]. Daha sonra filtre edilen solüsyon diğer aşamalarda yapılan toplam fenolik ve antioksidan kapasitelerinin belirlenmesinde kullanılmıştır.

Beta karoten ağartma metodunda Kaur ve Kapoor tarafindan bildirilen yöntemden yararlanılmıştır [12]. Bir balona $4 \mathrm{ml} \beta$-karoten çözeltisi, $40 \mathrm{mg}$ linoleik asit ve $400 \mathrm{mg}$ tween-40 konulmuştur. Hazırlanan karışımdaki kloroform uzaklaştırılıncaya kadar balon içeriği $50^{\circ} \mathrm{C}$ 'de evapore edilmiş ve bu balona $100 \mathrm{ml}$ oksijenlenmiş distile su eklenerek karıştırılmıştır. Deney tüpüne $800 \mu$ l örnek ekstraktı $200 \mu 1$ saf su konularak üzerine $3 \mathrm{ml} \beta$ karoten/linoleik asit çözeltisi ilave edilmiş ve spektrofotometrede $470 \mathrm{~nm}$ 'de absorbans ölçülmüştür. Standart madde olarak bütillenmiş hidroksi anisol (BHA) kullanılmıştır.

FRAP analizi (Ferric Reducing Antioxidant Power) için $0.1 \mathrm{~mol} / \mathrm{L}$ asetat (pH 3.6), $10 \mathrm{mmol} / \mathrm{L}$ TPTZ ve 20 mmol/L demir klorid çözeltileri (10:1:1) oranlarında karıştırılarak tampon çözelti hazırlanmıştır. Son olarak 30 $\mu \mathrm{L}$ meyve ekstraktına $2.97 \mathrm{~mL}$ hazırlanan buffer karıştırılarak absorbans 10 dakika sonra spektrofotometrede $593 \mathrm{~nm}$ dalga boyunda ölçülmüştür. Elde edilen absorbans değerleri Trolox $(10-100 \mu \mathrm{mol} / \mathrm{L})$ standart eğim tablosu ile hesaplanarak $\mu \mathrm{mol}$ Trolox eşdeğeri/g yaş meyve olarak sunulmuştur [13].

DPPH (2,2-diphenyl-1-picrylhydrazyl) (serbest radikal giderme) analizi ekstrelerin 2,2-difenil-1pikrilhidrazil (DPPH) üzerindeki serbest radikal süpürücü etkileri Sanchez-Moreno ve arkadaşlarının önerisine göre yapılmıştır [14]. Reaksiyon ortamındaki konsantrasyonu 4.3x10-3 mg/ml olacak şekilde hazırlanan örnek çözeltisinden $0.5 \mathrm{ml}$ alınıp 2x10-2 g/L konsantrasyonda \%70'lik metanol içinde hazırlanmış olan DPPH çözeltisinin $3 \mathrm{ml}$ sine ilave edilerek ve vortekste 30 saniye karıştırılarak oda sıcaklığında ve karanlıkta 30 dakika bekletilmiştir. Süre sonunda UV Spektrofotometresinde $517 \mathrm{~nm}$ de absorbans okunmuştur. 4.0x10-3 ve 2.0x10-2 g/L konsantrasyon aralı̆̆ında DPPH standardı kullanılarak hazırlanan kalibrasyon denklemi kullanılarak reaksiyon ortamındaki DPPH konsantrasyonu $(\mathrm{g} / \mathrm{L})$ hesaplanmıştır. 30 dakika sonucunda reaksiyon ortamında kalan DPPH miktarı hesaplanarak sonuca ulaşılmıştır. 
CUPRAC yöntemi bakır II neocuprain kompleksine dayanmaktadır (Cu-II- Nc). $1 \mathrm{ml}$ Bakır II neocuprain ve NH4Ac buffer çözeltisi, meyvenin asitlendirilmiş ve asitlendirilmemiş metanol ekstrakt çözeltisi (x, ml) ve su (1.1-x, ml) son hacim $4.1 \mathrm{ml}$ olacak şekilde ilave edilmiş ve absorbans değeri $450 \mathrm{~nm}$ 'de köre karş1 okunmuştur $[15]$.

\subsection{Fitokimyasal içerik}

Meyvelerdeki total fenolik bileşik tayini Folin-Ciocalteu reaktifi ile spektrofotometrik olarak tayin edilmiş ve standart olarak gallik asit kullanılmıştır. Ekstrakttan $1 \mathrm{ml}$ erlenmayere aktarılarak üzerine $46 \mathrm{ml}$ destile su ve $1 \mathrm{ml}$ Folin- Ciocalteau çözeltisi eklenerek karıştırılıp 3 dakika bekletildikten sonra \%2'lik sodyum karbonat çözeltisinden $3 \mathrm{ml}$ ilave edilmiş ve 2 saat karıştırıcıda karıştırılmıştır. Sonuçlar gallik asit eş değeri ( $\mu \mathrm{g} \mathrm{GAE} / \mathrm{mg}$ örnek) olarak verilmiştir [16].

Araştırma tesadüf parselleri deneme desenine göre kurulmuştur. Araştırmada ortalamalar arasındaki farklılıklar Duncan çoklu karşılaştırma testleri ile belirlenmiştir.

\section{Araştırma Bulguları ve Tartışma}

\subsection{Pomolojik ölçümler}

Yabani elmanın bazı pomolojik özellikleri Tablo 1'de verilmiştir. Meyvelerin eni 30.20 ile $36.01 \mathrm{~mm}$ arasında iken boyu 26.16 ile $31.24 \mathrm{~mm}$ aralığındadır. Meyvelerin ağırlığı $15.23 \pm 2.7 \mathrm{~g}$, hacmi ise $17.16 \pm 2.8 \mathrm{~cm}^{3}$ olarak saptanmıştır. Çekirdek sayısı ise $9 \pm 1$ olarak tespit edilmiştir.

Tablo 1. Yabani ekşi elmaya ait pomolojik özellikler.

\begin{tabular}{|l|l|}
\hline Pomolojik özellikler & Değerler \\
\hline Meyve boyu $(\mathrm{mm})$ & $28.82 \pm 1.56$ \\
\hline Meyve eni $(\mathrm{mm})$ & $32.73 \pm 1.47$ \\
\hline Meyve ağırlığı $(\mathrm{g})$ & $15.23 \pm 2.7$ \\
\hline Meyve hacmi $\left(\mathrm{cm}^{3}\right)$ & $17.16 \pm 2.8$ \\
\hline Çekirdek sayısı (adet) & $9 \pm 1$ \\
\hline
\end{tabular}

\subsection{Fizikokimyasal özellikler}

Yabani ekşi elmaya ait kimyasal ve fizikokimyasal özelliklere ait değerler Tablo 2'de verilmiştir. Ulaşılan sonuçlar Kaya (2019)'un çalışmasındaki SÇKM (13.29), toplam kuru madde (21.38), su aktivitesi (0.96) sonuçlarla benzerlik göstermiştir [17].

Tablo 2. Yabani ekşi elmaya ait fizikokimyasal özellikler.

\begin{tabular}{|l|l|}
\hline Fiziksel özellikler & Değerler \\
\hline Kuru madde (\%) & $16.06 \pm 0.49$ \\
\hline Suda Çözünebilir Kuru Madde (SÇKM \%) & $13.35 \pm 0.09$ \\
\hline Askorbik asit (C vitamini) (mg/l) & $30.7 \pm 1.6$ \\
\hline Toplam asitlik (g/l) & $2.95 \pm 0.01$ \\
\hline Malik asit (mg/l) & $9.6 \pm 0.02$ \\
\hline Glikoz (mg/l) & $46.0 \pm 0.2$ \\
\hline Su aktivitesi & $0.93 \pm 0.01$ \\
\hline
\end{tabular}




\subsection{Kurutma yöntemlerine göre fizikokimyasal özelliklerin değişimi}

Uygulanan dört farklı kurutma yöntemine (IR: Infrared kurutma, O: Oda sıcaklığında, E: Sicak hava, L: Dondurarak-Liyofilize) göre ürün özelliklerindeki değişimler aşağıda sunulmaktadır. Kurutulmuş yabani-ekşi elmaya ait kuru madde ve renk değerleri Tablo 3'te sunulmuştur. Kurutma sonucunda kuru madde değerleri \%84 ile \%95 arasında değişkenlik göstermektedir.

Tablo 3. Farklı yöntemlerle kurutulan yabani ekşi elmaya ait kuru madde ve renk değerleri.

\begin{tabular}{|l|c|c|c|c|}
\hline Koşullar & KM (\%) & $\mathbf{L}^{*}$ & $\mathbf{a}^{*}$ & $\mathbf{b}^{*}$ \\
\hline IR & $95.38 \pm 0.35^{\mathrm{a}}$ & $47.79 \pm 0.97^{\mathrm{bc}}$ & $9.78 \pm 0.64^{\mathrm{b}}$ & $22.01 \pm 1.79^{\mathrm{ab}}$ \\
\hline $\mathbf{O}$ & $90.42 \pm 0.34^{\mathrm{c}}$ & $48.78 \pm 1.24^{\mathrm{b}}$ & $8.39 \pm 0.85^{\mathrm{c}}$ & $23.46 \pm 0.54^{\mathrm{a}}$ \\
\hline $\mathbf{L}$ & $91.79 \pm 0.17^{\mathrm{b}}$ & $61.18 \pm 0.53^{\mathrm{a}}$ & $5.47 \pm 0.52^{\mathrm{d}}$ & $21.66 \pm 0.31^{\mathrm{ab}}$ \\
\hline $\mathbf{E}$ & $84.65 \pm 0.26^{\mathrm{d}}$ & $46.37 \pm 0.65^{\mathrm{c}}$ & $12.70 \pm 0.27^{\mathrm{a}}$ & $21.00 \pm 0.39^{\mathrm{b}}$ \\
\hline
\end{tabular}

Dört farklı kurutma yöntemine bakıldığında en yüksek kuru madde miktarı infrared (IR) kurutma yönteminde (\%95.38), en düşük kuru madde miktarı ise sıcak havada (E) kurutma yönteminde (\%84.65) ortaya çıkmıştır. Kuru madde miktarı elma meyvelerinin kurutularak ya da sofralık olarak tüketilebilirliğinin belirlenmesinde önemli bir parametredir. Yapmış olduğumuz çalışmada yabani ekşi elma meyvesinin yüksek kuru madde miktarına sahip olduğu ve kurutma işlemi için uygun olduğu belirlenmiştir.

Gıda ve tarımsal materyallerin kalite parametrelerinden birisi de renk özellikleridir. Çok fazla renk değişimleri ürün kalitesini etkileyerek pazarlamayı olumsuz şekilde etkileyecektir [18]. Elde edilen bulgulara göre, $L, a$ ve $b$ değerleri üzerinde kurutma yöntemlerine göre önemli değişimler meydana gelmektedir. L değeri (0:siyah, 100:beyaz) en yüksek değerini dondurarak kurutma yönteminde almıştır. a* değeri esmerleşme ile doğrudan etkili olan faktör olmakla birlikte elma en yüksek a* değerini sıcak havada kurutma yönteminde, en düşük değeri ise dondurarak kurutma yönteminde almıştır. En az değişim ise $b^{*}$ değerinde gözlenmiştir. Diğer yöntemlere ait değerler 46-48 arasında iken ortalama 61.18 ile diğer yöntemlere göre büyük farklılık göstermiştir. Dondurarak kurutma, dondurulmuş ürünün süblimasyon ile suyun uzaklaştırılması esasına dayanmaktadır ve düşük sıcaklık altında vakumla gerçekleştirilmektedir. Bu nedenle olumlu renk değişimi gözlenmektedir.

\subsection{Farklı kurutma yöntemlerinin yabani ekşi elmanın biyoaktif bileşenleri üzerine etkisi}

Elmaların antioksidan aktivite analizlerinde ABTS yönteminden sonuç alınamamıştır. Farklı yöntemlerle kurutulan yabani ekşi elmanın antioksidan aktivite değerleri ve fenolik madde içerikleri Tablo 4 'te sunulmuştur.

Tablo 4. Farklı yöntemlerle kurutulan yabani ekşi elmanın antioksidan ve fenolik madde miktarı

\begin{tabular}{|l|c|c|c|c|c|}
\hline $\begin{array}{c}\text { Kurutma } \\
\text { yöntemi }\end{array}$ & $\begin{array}{c}\text { Toplam Fenolik } \\
\text { Madde } \\
(\mathrm{mgGAE} / \mathrm{gK})\end{array}$ & $\begin{array}{c}\text { DPPH } \\
(\mu \mathrm{mol} \text { TE/KM })\end{array}$ & $\begin{array}{c}\text { FRAP } \\
(\mu \mathrm{mol} \text { TE/KM })\end{array}$ & $\begin{array}{c}\text { CUPRAC } \\
(\mu \mathrm{mol} \text { TE/KM })\end{array}$ & $\begin{array}{c}\text { Beta Karoten } \\
(\%)\end{array}$ \\
\hline $\mathrm{IR}$ & $35.87 \pm 4.65$ & $19.32 \pm 0.77^{\mathrm{b}}$ & $163.5 \pm 4.9^{\mathrm{c}}$ & $132.8 \pm 2.58^{\mathrm{c}}$ & $35.95 \pm 0.63^{\mathrm{d}}$ \\
\hline $\mathrm{O}$ & $34.92 \pm 2.05$ & $18.14 \pm 0.49^{\mathrm{b}}$ & $143.5 \pm 3.5^{\mathrm{d}}$ & $124.7 \pm 2.33^{\mathrm{d}}$ & $55.80 \pm 2.74^{\mathrm{c}}$ \\
\hline $\mathrm{L}$ & $38.07 \pm 1.93$ & $19.11 \pm 1.78^{\mathrm{b}}$ & $213.7 \pm 6.1^{\mathrm{a}}$ & $154.82 \pm 0.96^{\mathrm{b}}$ & $65.63 \pm 1.50^{\mathrm{b}}$ \\
\hline $\mathrm{E}$ & $41.18 \pm 2.81$ & $28.15 \pm 1.08^{\mathrm{a}}$ & $200.8 \pm 4.3^{\mathrm{b}}$ & $162.25 \pm 3.19^{\mathrm{a}}$ & $62.17 \pm 2.35^{\mathrm{b}}$ \\
\hline \multicolumn{7}{|l|}{} & BHA & $92.06 \pm 0.14^{\mathrm{a}}$ \\
\hline
\end{tabular}

Elma posasında bulunan polifenoller elmanın işlenmesiyle meyve suyuna geçmektedir. Burada ortaya çıkan yüksek antioksidan aktivite oranı, meyvede bulundurulan flavanol ve flavonollerden ileri gelmektedir [19]. Elma posasından, kateşinler, hidroksisinnamatlar, floretin glikozidleri, kursetin glikozidleri, prosiyanidinler gibi pek çok majör bileşenler izole edilmiş ve tanımlanmıştır [20, 21].

Çalışmada kullanılan elma örneklerinin ortalama fenolik madde içerikleri 35.87 - 41.18 mg GAE/g KM arasında değişiklik göstermiştir. En yüksek değer $41.18 \mathrm{mg}$ GAE/g KM ile sıcak hava yöntemi ile kurutulmuş elmalarda saptanırken elde edilen bulgular istatistik olarak değerlendirildiğinde kurutma yöntemleri ile fenolik madde miktarı arasında anlamlı bir farklılık tespit edilememiştir $(\mathrm{p}>0.05)$. 
Toplam fenolik madde içeriği ile antioksidan aktivite yöntemleri arasında yapılan korelasyona göre ortalama fenolik madde içeriği değerleri CUPRAC, DPPH ve FRAP yöntemleriyle kısmi korelasyon göstermiştir ve $r$ değerleri sirasılyla $0.711,0.655,0.587$ olarak belirlenmiştir $(\mathrm{p}<0.05)$.

En yüksek antioksidan kapasite değeri FRAP yönteminde $(213 \mu \mathrm{mol} \mathrm{TE} / \mathrm{KM})$ elde edilmiştir. FRAP yöntemini CUPRAC yöntemi takip etmektedir. Elmalar antioksidan aktivite yöntemleri açısından değerlendirildiğinde DPPH sonuçları 18.14-28.15 arasında, FRAP sonuçları 143.5-213.7 arasında CUPRAC sonuçları ise 132.80- $162.25 \mu \mathrm{mol} \mathrm{TE} / \mathrm{KM}$ arasında tespit edilmiştir. Değerler arasındaki farklılıkların antioksidan yöntemlerinin dayandığı ilkelerin aynı olmamasından kaynaklandığı düşünülmektedir. Metotlar arasında yapılan bivaryete korelasyon incelendiğinde CUPRAC metodu ile FRAP metodu arasında yüksek bir korelasyon olduğu saptanmıştır $\left(\mathrm{r}=0.939, \mathrm{R}^{2}=\% 88\right)$. Burada uygulanan kurutma yöntemlerinin benzeri araştırmalarda sıklıkla tercih edildiği görülmüştür [22]

DPPH ile Beta karoten yöntemleri arasında negatif yüksek korelasyon tespit edilmiştir ( $\left.\mathrm{r}=0.866, \mathrm{R}^{2}=\% 75\right)$. Başka bir ifadeyle DPPH değerlerinde artış gözlemlendiğinde Beta karoten yönteminde elde edilen sonuçlarda azalma görülmektedir.

Beta karoten yönteminde referans olarak kullanılan BHA'nın antioksidan aktivitesi \%92 olarak tespit edilmiştir. Süre sonunda (90 dakika) dondurarak kurutma $\% 65$ ve sıcak havada kurutma ise $\% 62$ antioksidan aktivite gösterirken değerler arasında istatistik olarak fark bulunamamıştır $(\mathrm{p}>0.05)$.

Antioksidan aktivite ve fenolik madde miktarı (FRAP yönteminde elde edilen sonuçlar hariç) açısından en yüksek değer sıcak havada kurutma yöntemi ile tespit edilmiştir.

\section{Sonuc}

Meyvelerde bulunan bazı bileşenler ve su kimyasal ve mikrobiyolojik bozulmalara yol açmaktadır. Bu durum meyvelerin hasat mevsiminin dışındaki zamanlarda kullanımını sınırlandırmaktadır. Bu durumla başa çıkılabilmesi için önerilen yollardan bir tanesi de meyvelerin farklı yöntemlerle kurutularak muhafaza edilmesidir. Bu çalışmada ana materyal olarak kullanılan yabani ekşi elma meyvesi çok bilinen bir tür olmamakla birlikte organik bir meyve olup daha önce yapılan çalışmalara bakıldığında besinsel olarak önemli bileşenlere sahiptir. Bu nedenle bu meyvenin hasat mevsiminin dışında kalan zamanlarda da en faydalı şekilde tüketilebilmesi için en uygun şartlarda kurutulması gerektiği düşünülmektedir.

Kuru madde miktarı diğer meyvelerde olduğu gibi yabani ekşi elma için de kurutularak ya da sofralık olarak tüketilebilirliğinin belirlenmesinde önemli bir ölçüttür. Yapmıș olduğumuz çalışmada yabani ekși elma meyvesinin yüksek kuru madde miktarına sahip olduğu ve kurutma ișlemi için uygun olduğu belirlenmiștir.

Elde edilen deneysel verilere göre, antioksidan ve fenolik madde içeriği açısından yabani ekși elma (Malus sylvestris Miller)' nın en iyi kurutma yöntemi sıcak havada kurutma yöntemi olarak tespit edilmiştir. Renk değerleri ve esmerleşme açısından ise en iyi yöntem dondurarak kurutma yöntemidir. Ancak bu yöntem diğer yöntemlere göre daha maliyetli bir teknik olması açısından endüstriyel anlamda kullanılması tercih edilmemesine neden olabilir. Diğer yöntemlerde renk değiş̧iminin önüne geçebilmek için kükürt dioksit $\left(\mathrm{SO}_{2}\right)$ ya da askorbik asit kullanılabilir.

Antioksidan aktivite, meyvenin yetiștiği iklim, toprak, stres koșulları gibi faktörlerden, saklama koşulları ve süresinden etkilenebilir. Antioksidan aktiviteleri DPPH yöntemine göre; sıcak havada kurutma yöntemi diğer yöntemlere göre en yüksek değeri vermiştir. FRAP yöntemine göre "dondurarak kurutma > sıcak havada kurutma > infrared > oda sıcaklığı" şeklinde, CUPRAC yöntemine göre ise; "sicak havada kurutma > dondurarak kurutma $>$ infrared $>$ oda sıcaklığı" șeklinde, Beta karoten yönteminde ise sıralama BHA> dondurarak kurutma $>$ sıcak havada kurutma $>$ oda sıcaklı̆̆ı $>$ infrared șeklinde değișim gösterdiği görülmüștür. CUPRAC metodu ile FRAP metodu arasında yüksek bir korelasyon olduğu saptanmıştır $\left(\mathrm{r}=0,939, \mathrm{R}^{2}=\% 88\right)$.

Ulaşılan sonuçlara göre bu meyvenin taze ya da kurutulmuş olarak birçok farklı gıda sektöründe ve ürün içinde kullanılabileceği ve bu şekilde ekonomik bir ürün haline dönüștürülebileceği anlaşılmaktadır.

\section{Teșekkür}

Bu çalışma Kübra Güldemir'in yüksek lisans tezinden türetilmiş olup, çalışmanın bir kısmı BAP- 2014/0112 sayılı proje kapsamında Bayburt Üniversitesi Bilimsel Araştırma Projeleri Koordinasyon Birimi tarafından desteklenmiştir. 


\section{Kaynaklar}

[1] Burak M, Ergun M. Elma Sekizinci Beş Yıllık Kalkınma Planı Bitkisel Üretim Özel İhtisas Komisyonu. Meyvecilik Alt Komisyonu Elma Raporu Başbakanlık Devlet Planlama Teşkilatı Yayını, Ankara, 2000; 16-54.

[2] Sun J, Chu Y, Wu X, Liu RH. Antioxidant and Antiproliferative Activities of Common Fruits. J Agr Food Chem 2002; 50, 7449-7454.

[3] Boyer J, Liu RH. Apple Phytochemicals And Their Health Benefits. Nutrition Journal 2004a; 3, 1-15.

[4] Boyer J, Liu RH. Antioxidants of Apples. New York Fruit Quarterly 2004b. Volume 11, Number 4.

[5] Drogoudi DP, Michailidis Z, Pantelidis G. Peel And Flesh Antioxidant Content And Harvest Quality Characteristics of Seven Apple Cultivars. Scientia Horticulture 2008; 115, 149 - 153.

[6] Eberhardt M, Lee C, Liu LH. Antioxidant Activity Of Fresh Apples. Nature 2000; 405, 903-904.

[7] Sampath C, Rashid MR, Sang S, Ahmedna M. Specific bioactive compounds in ginger and apple alleviate hyperglycemia in mice with high fat diet-induced obesity via Nrf2 mediate pathway. Food Chem. 2017; 226, 79-88.

[8] Opyd PM, Jurgoński A, Juśkiewicz J, Milala J, Zduńczyk Z, Król B. Nutritional and Health-Related Effects of a Diet Containing Apple Seed Meal in Rats: The Case of Amygdalin. Nutrients 2017 ; 9(10).

[9] Güldemir K. Bayburt İlinde Doğal Olarak Bulunan yabani ekşi elma (Malus sylvestris Miller)'nın Farklı Yöntemlerle Kurutularak Antioksidan ve Fenolik Madde İçeriklerinin Belirlenmesi. Yüksek Lisans Tezi, Bayburt, Türkiye, 2016.

[10] Djekic I, Tomic N, Bourdoux S, Spilimbergo S, Smigi N, Udovicki B, Hofland G, Devlieghere F, Rajkovic A. Comparison of three types of drying (supercritical CO2, air and freeze) on the quality of dried apple - Quality index approach. LWT-Food Science and Techonology. 2018 (94) 64-72

[11] Çolak N, Zengin AY, Ayaz FA. The Effect Of Anthocyanin-Rich Bilberry Extract On The Antioxidant System İn Roots Of Barley Cultvars Under İonizing Radiation. Acta Physiol Plant. 2015; 37:187.

[12] Kaur C, Kapoor HC. Anti-Oxidant Activity and Total Phenolic Content of Some Asian Vegetables. Int. J. Food Sci. and Technol., 2002; 37: 153-161.

[13] Benzie IFF, Strain JJ. The Ferric Reducing Ability Of Plasma (Frap) As A Measure Of “Antioxidant Power”: The Frap Assay. Anal. Biochem., 1996; 239 (1):70-76.

[14] Sanchez-Moreno C. Review. Methods used evaluate the free radical scavenging activitiy in biological systems. Food Sci. Technol. Int., 2002; 8(3): 121-137.

[15] Apak R, Güçlü K, Ozyurek M, Karademir S.E, Altun M. Total Antioxidant Capacity Assay of Human Serum Using Copper(II)-Neocuproine as Chromogenic Oxidant: The CUPRAC Method. Free Radical Research, 2005; 39, 949-961.

[16] Gülcin I, Oktay M, Kufrevioglu I, and Aslan A. Determination of antioxidant activity of lichen Cetraria islandica (L) Ach. Journal of Ethnopharmacology. 2002; 79 (3) 325-329.

[17] Kaya, ZG., Ultrases Ön İşlemiyle Sicak Hava Ve Mikrodalga Sistemlerinde Kurutulan Elma Dilimlerinin Kalite Özelliklerinin Belirlenmesi, Süleyman Demirel Üniversitesi Fen Bilimleri Enstitüsü Gıda Mühendisliği Anabilim Dalı, Yüksek Lisans Tezi, 2019.

[18] Nasıroğlu Ş. Kırmızı Biber, Elma ve Pırasanın Kurutulmasında İnfrared Kurutma Tekniğinin Kullanılması. Yüksek Lisans Tezi, Çanakkale Onsekiz Mart Üniversitesi, Çanakkale, Türkiye, 2007.

[19] Garcia Y, Valles B, Lobo A. Analytical Methods Phenolic and Antioxidant Composition Of By-Products From The Cider Industry: Apple Pomace. Food Chem. 2009; 117: 731-738.

[20] Lommen A, Godejohann M, Venema D, Hollman P, Spraul M. Application Of Directly Coupled Hplc-Nmr-Ms To The Identification And Confirmation Of Quercetin Glycosides And Phloretin Glycosides In Apple Peel. Anal. Chem., 2000; 72:1793-1797.

[21] Schieber A, Hilt P, Streker P, Endre H, Rentschler C, Carle R. A New Process For The Combined Recovery Of Pectin And Phenolic Compounds From Apple Pomace. Innovative Food Sci. Emerging Technol. 2003; 4: 99-107.

[22] Karataş N. Farklı kurutma yöntemlerinin bazı kayısı çeşitlerinin kimyasal ve fiziksel özelliklerine etkisi. Doktora tezi, Atatürk Üniversitesi, Fen Bilimleri Enstitüsü, Gıda Mühendisliği Anabilim Dalı, Türkiye, 2014. 